Revista Brasil. Bot., V.28, n.4, p.755-763, out.-dez. 2005

\title{
Diurnal variations of non-structural carbohydrates in vegetative tissues of Melinis minutiflora, Echinolaena inflexa and Lolium multiflorum (Poaceae)
}

\author{
AMANDA DE SOUZA ${ }^{1}$, CARLA Z. SANDRIN ${ }^{1}$, MOEMY G. MORAES ${ }^{2}$ and \\ RITA DE CÁSSIA L. FIGUEIREDO-RIBEIRO ${ }^{1,3}$
}

(received: November 11, 2004; accepted: October 20, 2005)

\begin{abstract}
Diurnal variations of non-structural carbohydrates in vegetative tissues of Melinis minutiflora, Echinolaena inflexa, and Lolium multiflorum - Poaceae). Echinolaena inflexa (Poir.) Chase is a native $\mathrm{C} 3$ grass species with high biomass production and abundance in the cerrado comparable to Melinis minutiflora Beauv., a $\mathrm{C} 4$ forage grass of African origin, widespread in the cerrado, displacing some native herbaceous species. These species accumulate mainly starch, differently of Lolium multiflorum Lam. ssp. italicum Beck cv. Lema (ryegrass), a C3 temperate forage grass that accumulates fructans as the major storage carbohydrate in the vegetative tissues. In the present study, we analyzed diurnal variations in the content and composition of non-structural carbohydrates (NSC) in the aerial vegetative parts of the three species. Results showed similarity in water-soluble carbohydrates (WSC) and starch contents between Melinis minutiflora and Echinolaena inflexa, with the exotic grass accumulating higher amounts of NSC. However, the levels of sucrose, glucose and fructose were 10 fold higher in Lolium multiflorum, that accumulates fructan as the main storage carbohydrate. Although the contents of WSC and starch were similar in the tropical species E. inflexa and M. minutiflora, their diurnal variations were different and could be related to starch metabolism, especially in M. minutiflora.
\end{abstract}

Key words - cerrado, fructans, Panicoideae, Pooideae, starch, sugars

RESUMO - (Variações diurnas nos carboidratos não-estruturais em tecidos vegetativos de Melinis minutiflora, Echinolaena inflexa and Lolium multiflorum - Poaceae). Echinolaena inflexa (Poir.) Chase (flexinha) é uma gramínea C3 nativa do cerrado, que apresenta produção de biomassa e abundância comparáveis às de Melinis minutiflora Beauv. (capim-gordura), uma gramínea $\mathrm{C} 4$, de origem africana e invasora do cerrado. Ambas espécies são perenes e armazenam amido como carboidrato de reserva, diferentemente de Lolium multiflorum Lam. ssp. italicum Beck cv. Lema, uma gramínea C3 de regiões de clima temperado, introduzida no sul do Brasil para fins forrageiros, que acumula frutanos como principal carboidrato de reserva em seus órgãos vegetativos. Neste trabalho foram analisadas as variações diurnas no conteúdo e na composição dos carboidratos-não estruturais (NSC) presentes na parte aérea dessas três espécies. Os resultados mostraram que os conteúdos de açúcares solúveis em água (WSC) e de amido são semelhantes em Melinis minutiflora e Echinolaena inflexa, sendo maiores na espécie invasora. Contudo, as maiores quantidades de WSC, especialmente de sacarose, glicose e frutose foram encontradas em Lolium multiflorum, gramínea acumuladora de frutanos. Embora os conteúdos de WSC e de amido nas gramíneas tropicais E. inflexa e M. minutiflora tenham sido semelhantes entre si, os padrões diurnos de variação desses compostos foram diferentes nessas espécies e parecem estar relacionados ao metabolismo de amido, especialmente em M. minutiflora.

Palavras-chave - açúcares, amido, cerrado, frutanos, Panicoideae, Pooideae

\section{Introduction}

Studies concerning non-structural carbohydrates (NSC) of grasses have focused mainly on sucrose, fructans (oligo- and polyfructosyl sucrose) and starch from their grazed products. Based on the type of stored carbohydrate (Ojima \& Isawa 1968, Smouter \& Simpson

\footnotetext{
1. Instituto de Botânica de São Paulo, Caixa Postal 4005, 01061-970 São Paulo, SP, Brasil.

2. Universidade Federal Fluminense, Caixa Postal 100436, 24001-970 Niterói, RJ, Brasil.

3._Corresponding author: ritarib@usp.br
}

1989) grasses are classified in two groups. One group is represented by fructan-accumulating species, native to temperate regions, which have mainly $\mathrm{C} 3$ photosynthesis. The other group includes species that accumulate mainly starch or sucrose, native to tropical regions and have $\mathrm{C} 3$ or $\mathrm{C} 4$ photosynthetic pathways (Chatterton et al. 1991). The concentrations of these sugars are highly variable on daily and seasonal timescales, as a function of several environmental factors (Cairns et al. 2002).

Because starch is a minor reserve in leaves of the fructan-grasses, the metabolism of transitory starch has received scant attention, even in plants which are starch- 
accumulating species (Smith et al. 2003) and little is known about the physiology of carbon partitioning between sucrose, fructan and starch in these species (Cairns et al. 2002).

It is well known that leaves accumulate sucrose and starch as well as export sucrose to the rest of the plant during the day. At night sucrose and starch are remobilised to maintain the export of sucrose to sink tissues and to support respiration in the leaf (Lunn \& Hatch 1995). However, diurnal variations in the patterns of starch, fructans, sucrose and hexoses in grasses are less studied.

Poaceae is one of the most representative families in the herbaceous stratum of the cerrado (Mantovani \& Martins 1988, Castro et al. 1999) and more than 50\% of the Brazilian herd, that is the forth of the world, depends on it for its food (Filgueiras 1991). Echinolaena inflexa (Poir.) Chase (arrow grass) is a C3 grass species from the cerrado with high biomass production and abundance comparable to Melinis minutiflora Beauv. (mollasses grass), that is a $\mathrm{C} 4$ forage grass of African origin. Both species belong to the predominantly tropical and subtropical subfamily Panicoideae, which has C3 and $\mathrm{C} 4$ plants, including other important forage grasses such as Brachiaria, Paspalum, Pennisetum, Urochloa and the cereals Sorghum and Zea and the sugar cane, Saccharum officinarum. In spite of their distinct origin and photosynthetic metabolism, Melinis minutiflora and Echinolaena inflexa have similar sugar contents and composition but low levels of water-soluble carbohydrates (WSC) when compared to temperate grasses (Moraes et al. 2002).

Lolium multiflorum Lam. (Italian ryegrass), subfamily Pooideae, like other C3 temperate forage grasses, accumulates fructose polymers as the major storage carbohydrate (Pollock \& Chatterton 1988). The predominant linkage pattern between adjacent fructose units is the levan type b-(2,6). Fructan accumulates in the stems after anthesis (Griffith 1992) or in the leaf sheaths and supports regrowth after defoliation (Pollock \& Jones 1979). L. multiflorum has been used for cattle pastures in the South of Brazil and also is widely utilized as a bioindicator of urban air pollution, since it accumulates heavy metals, sulphur and fluoride when growing in the presence of air pollutants (Domingos et al. 1998). Recently, it was shown that fructan metabolism in L. multiflorum was affected by air pollution (Sandrin et al. 2004). Plants grown in polluted sites accumulated larger amounts of high molecular weight fructans, when compared with plants cultivated in non-polluted sites.

In the present study we compare diurnal variations in the content and composition of NSC present in the vegetative aerial parts of Melinis minutiflora and Echinolaena inflexa, growing in the cerrado, with Lolium multiflorum to provide information on the dynamics of carbon partitioning in forage grasses storing different types of carbohydrates.

\section{Material and methods}

Plant material - Vegetative tissues of Melinis minutiflora Beauv. and Echinolaena inflexa (Poir.) Chase were harvested from plants growing in the Brazilian cerrado at the Biological Reserve of Moji-Guaçu (22 $15^{\circ}-22^{\circ} 16^{\prime} \mathrm{S}$ and $47^{\circ} 08^{\prime}-47^{\circ} 12^{\prime} \mathrm{W}$, located in Moji-Guaçu, SP, Brazil. Tillers were harvested from six plants randomly chosen for each of the two species. The harvested tillers represented the predominant phenological phase of both species in the studied area.

Seeds of Lolium multiflorum Lam. ssp. italicum Beck cv. Lema $(0.8 \mathrm{~g}$ per pot), obtained from the University of Hohenheim (Germany), were germinated and grown in plastic pots in a glasshouse with filtered air at the Institute of Botany (São Paulo, Brazil), in order to provide appropriate conditions for growth. During cultivation the plants were excised to a height of $4 \mathrm{~cm}$ and fertilized with nutrient solution $\left(40 \mathrm{~cm}^{3}\right.$ per pot) periodically. After eight weeks, the aerial vegetative tissues were harvested for extraction and analyses of carbohydrates.

The sampling of the three forage grasses was performed in one day during autumn at $8,10,12,14,16$, and 18 hours. This season was chosen because the largest amount of nonstructural carbohydrates is found in this period in the vegetative tissues of grasses from the cerrado (Moraes 2001). Extraction and analyses of non-structural carbohydrates (NSC) - After harvesting, water-soluble carbohydrates (WSC) were extracted from vegetative tissues in boiling $80 \%$ ethanol followed by water (Pollock \& Jones 1979). The aqueous and ethanolic extracts were pooled and concentrated in a rotary evaporator. Total sugars of E. inflexa and M. minutiflora were measured by the phenol-sulphuric acid procedure (Dubois et al. 1956), using glucose as standard; for L. multiflorum fructose-containing carbohydrates were measured by the anthrone reaction modified by Jermyn (1956), using fructose as standard. Aliquots of carbohydrate extracts were deionized using Sep-Pack Accell Plus QMA and CM cartridges and hydrophobic compounds were removed using Sep-Pack $\mathrm{tC}_{18}$ cartridges. All cartridges used were supplied by Waters Chromatography Division of Millipore Co. (USA).

Oligosaccharides and fructans were analyzed by high performance anion exchange chromatography with pulsed amperometric detection (HPAEC-PAD), on a Dionex DX-300, in a CarboPac PA-1 $(4 \times 250 \mathrm{~mm})$ column, using a linear gradient of sodium acetate in sodium hydroxide $(150 \mathrm{mM})$ or in a CarboPac PA-100 $(4 \times 250)$ column, according to Itaya et al. (1997). The elution program consisted of a sodium hydroxide gradient $\left(1 \mathrm{~cm}^{3} \cdot \mathrm{min}^{-1}\right)$ of $12 \mathrm{mM}(0-2 \mathrm{~min})$, 
$24 \mathrm{mM}$ (2-5 min ), $44 \mathrm{mM}$ (5-9 min), $54 \mathrm{mM}$ (9-13 min), $62 \mathrm{mM}$ (13-16 min), 66 mM(16-18), $96 \mathrm{mM}(18-25 \mathrm{~min}), 120 \mathrm{mM}(25-30)$, $140 \mathrm{mM}(35-40 \mathrm{~min})$ and $12 \mathrm{mM}$ (41 min). Quantification of individual sugars was performed according to Timmermans et al. (1994) by the external standard method using authentic standards (Sigma).

Starch analysis was performed according to the method proposed by Arêas \& Lajolo (1980), modified as follows: $10 \mathrm{mg}$ of ground dry material was weighed in Eppendorf tube and submitted to extraction with $80 \%$ ethanol (v/v) at $80^{\circ} \mathrm{C}$. After centrifugation at $13.000 \mathrm{~g}$ for $5 \mathrm{~min}$, the supernatant was discarded. This procedure was repeated twice. The residue was solubilized in $1.5 \mathrm{~mL}$ of $50 \mathrm{mM} 3$-[N-morpholin] propansulfonic acid buffer (MOPS), $\mathrm{pH} 7.0$, at $30^{\circ} \mathrm{C}$ for $1 \mathrm{~h}$. To initiate the digestion, $28 \mathrm{U} / \mathrm{mL}$ of $\alpha$-amylase (Megazyme) in $50 \mathrm{mM} 3$-[N-morpholin] propan-sulfonic acid buffer (MOPS), $\mathrm{pH} 7.0$, were added and the extract was incubated for $1 \mathrm{~h}$ at $70{ }^{\circ} \mathrm{C}$. After incubation, $1 \mathrm{~mL}$ of $300 \mathrm{mM}$ sodium acetate buffer, $\mathrm{pH} 4.8$, was added and a new incubation was performed with $28 \mathrm{U} / \mathrm{mL}$ of amyloglucosidase (Megazyme) in $100 \mathrm{mM}$ sodium acetate buffer, $\mathrm{pH} 4.8$, for $30 \mathrm{~min}$ at $50^{\circ} \mathrm{C}$. The reaction was stopped by the addition of $10 \% 0.8 \mathrm{M}$ percloric acid. Free glucose content was determined using a glucose oxidase/ peroxidase (GOD/POD) "kit" appropriated for Elisa (Centerlab). An aliquot of the mixture was transferred to a tube and $150 \mu \mathrm{L}$ of glucose oxidase were added. After incubation for $15 \mathrm{~min}$ at $30^{\circ} \mathrm{C}$, free glucose was quantified by spectrophotometry at $490 \mathrm{~nm}$.

\section{Results}

Figure 1 shows the general aspects of the aerial organs of Echinolaena inflexa (figure 1A, 1B), Melinis minutiflora (figure 1E, 1F) and Lolium multiflorum (figure 1C, 1D).

The HPAEC/PAD profiles of water-soluble carbohydrates (WSC) extracted from the vegetative tissues of the analyzed species indicated that glucose, fructose, and sucrose are the main soluble sugars present in the tropical grasses $M$. minutiflora and E. inflexa (figure 2A, 2B), while fructans of varying sizes comprised the major portion of soluble carbohydrates found in the aerial parts of the Italian ryegrass (figure 2C). Higher proportions of sucrose, glucose and fructose were also found in L. multiflorum (figure 2C). Traces of raffinose and maltose-based oligosaccharides were also found in the two tropical grasses (figure 2A, 2B), mainly in the stems of $E$. inflexa (figure $3 \mathrm{~A}$ ). The identity of these glucans was confirmed by acid hydrolysis, producing only glucose as the reaction product.

Figure 4 shows changes in the contents of total WSC, starch and fructans during the daylight period in the three grasses. In M. minutiflora (figure 4A), the levels of WSC were approximately two fold higher than those found in E. inflexa, in which a slight increase at the beginning of the light period and a decrease to initial levels in the afternoon was observed (figure 4B). The starch content was also higher in M. minutiflora than in the native species, presenting an almost linear increase from $8 \mathrm{~h}$ to $12 \mathrm{~h}$ (figure 4A). In E. inflexa the starch content was nearly constant between $8 \mathrm{~h}$ and $16 \mathrm{~h}$ (figure 4B), increasing at the end of the day. Diurnal variations of WSC (mono- and disaccharides) and total fructans in L. multiflorum are shown in figure $4 \mathrm{C}$, indicating a similar pattern of variations between the two carbohydrate fractions, with two peaks, one at $10 \mathrm{~h}$ and another one around $16 \mathrm{~h}$. The total amount of WSC in L. multiflorum was seven to ten times higher than in the two tropical grasses.

Quantifications of glucose, fructose and sucrose by HPAEC-PAD in the three grasses (figure 5) show that the levels of glucose were higher in M. minutiflora than in E. inflexa, mainly at $8 \mathrm{~h}, 14 \mathrm{~h}$ and $18 \mathrm{~h}$ (figure 5A). Similarly to L. multiflorum (figure 5B), the content of glucose was more constant in the native species than in M. minutiflora, in which glucose presented fluctuations, with marked decreases observed at $10 \mathrm{~h}$ and at $16 \mathrm{~h}$.

In both E. inflexa and M. minutiflora, the levels of fructose and sucrose (figure 5C, E) were lower than those observed for glucose. Both species showed few variations in the fructose content. E. inflexa had a slight decrease in the afternoon, and M. minutiflora at $10 \mathrm{~h}$ (figure 5C). The native species also showed constant levels of sucrose (figure 5E), with a slight increase at $12 \mathrm{~h}$, while $M$. minutiflora presented a more pronounced increase in the disaccharide content at the same time of the day (figure 5E). However, the levels of sucrose, glucose and fructose in the two tropical grasses were ten fold lower than in L. multiflorum. The diurnal variations in the content of sucrose in L. multiflorum followed the same pattern found for fructans (figure 4C).

\section{Discussion}

Poaceae is one of the most important among Angiosperm families accumulating fructans (Pollock \& Cairns 1991). In this group, fructans are present in one of the major subfamily, the Pooideae or northern grasses, which include the cereals wheat, oats, barley and rye and also important forage grasses such as Festuca, Agrostis, Lolium and Poa. According to Hendry (1993), if the genes for fructan synthesis are present in the other 

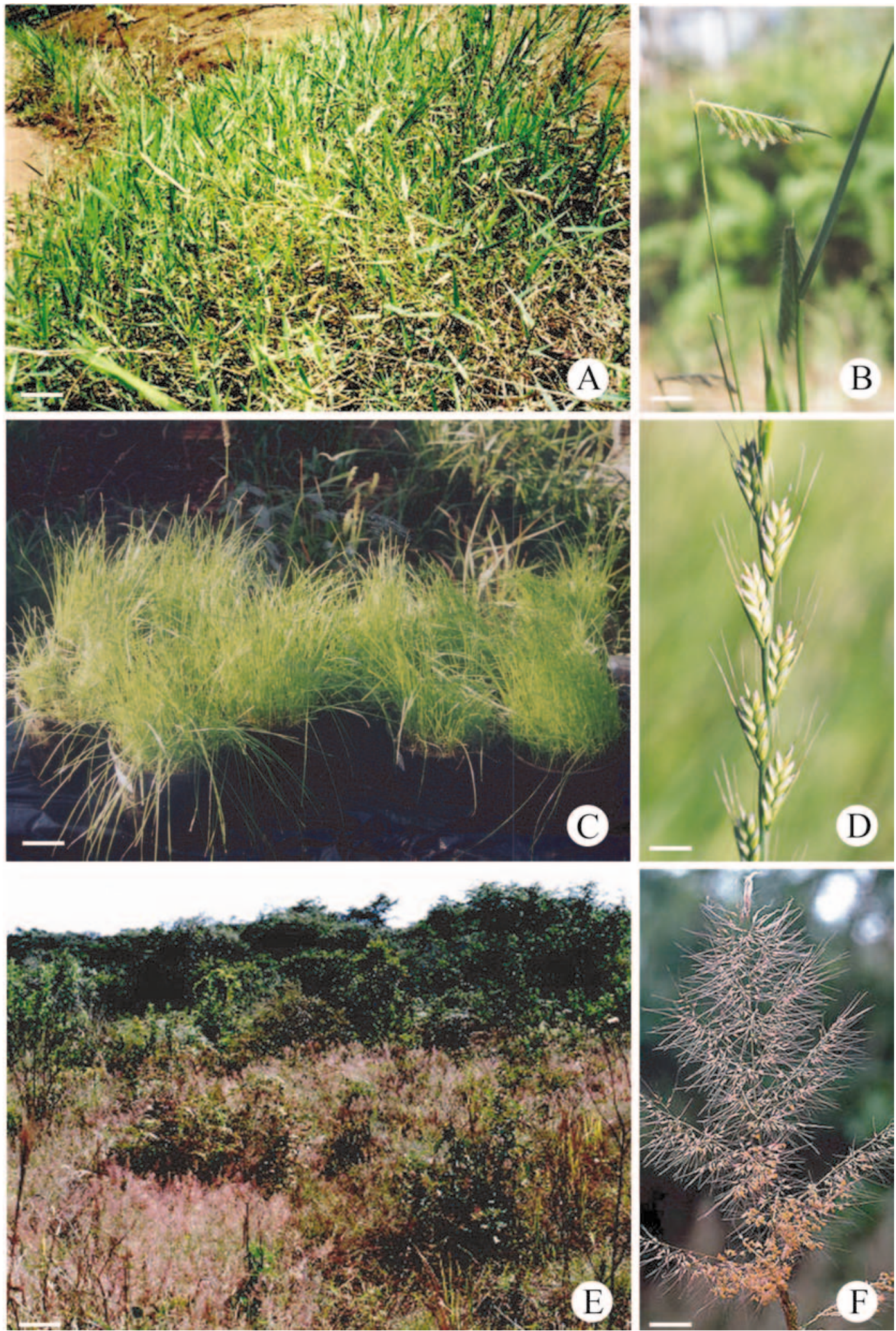

Figure 1. General view of the tropical grasses Echinolaena inflexa (A) and Melinis minutiflora (E), growing in the cerrado in Moji-Guaçu (SP), and the temperate grass Lolium multiflorum (C) growing in a glasshouse with filtered air in the Institute of Botany (São Paulo, SP). Details of the inflorescences from plants of E. inflexa (B), M. minutiflora (F) and L. multiflorum (D). Bars $=7.5 \mathrm{~cm}(\mathrm{~A}) ; 1.4 \mathrm{~cm}(\mathrm{~B}) ; 7.5 \mathrm{~cm}(\mathrm{C}) ; 1 \mathrm{~cm}(\mathrm{D}) ; 1.8 \mathrm{~cm}(\mathrm{~F})$. Photos are by Igor Ferrari Borges, except $\mathrm{F}$, which is by Clifford W. Smith. 
Poaceae subfamilies, they are not expressed to any great extent in species predominantly of tropical distribution, including Arundinoideae, Bambusoideae, Chloridoideae and Panicoideae subfamilies. M. minutiflora and E. inflexa belong to the Panicoideae. Indeed, fructans were not detected in the aerial vegetative parts in either
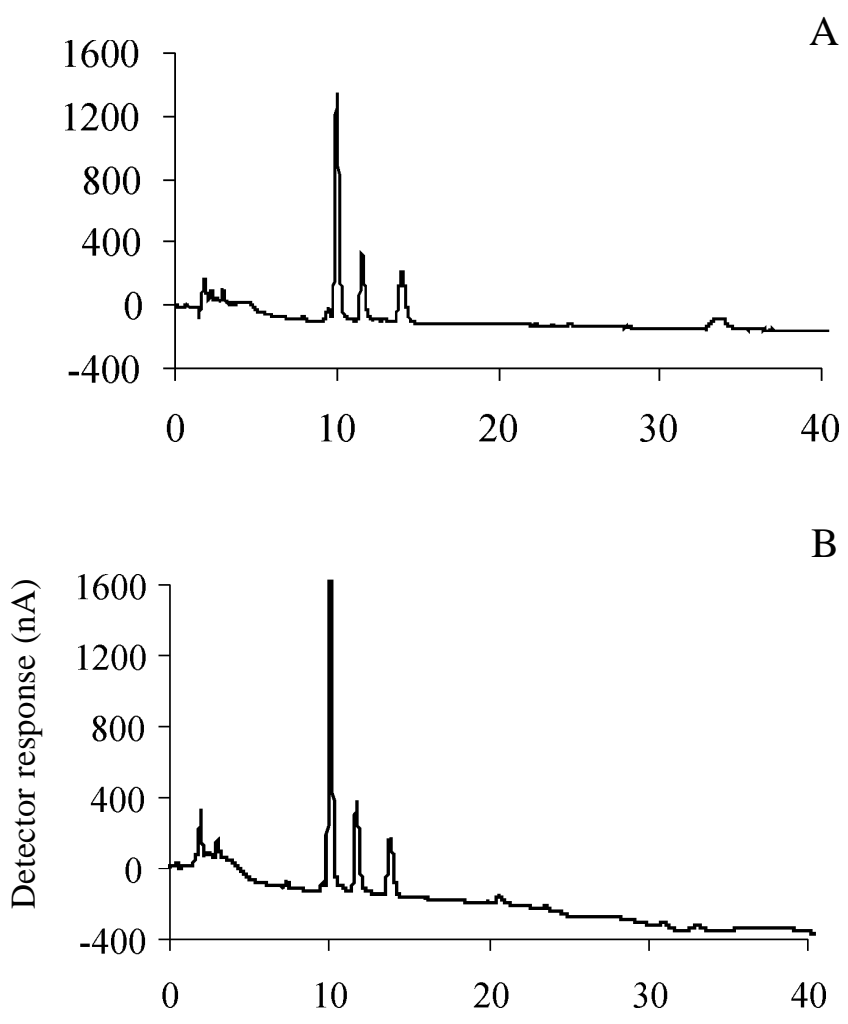

C

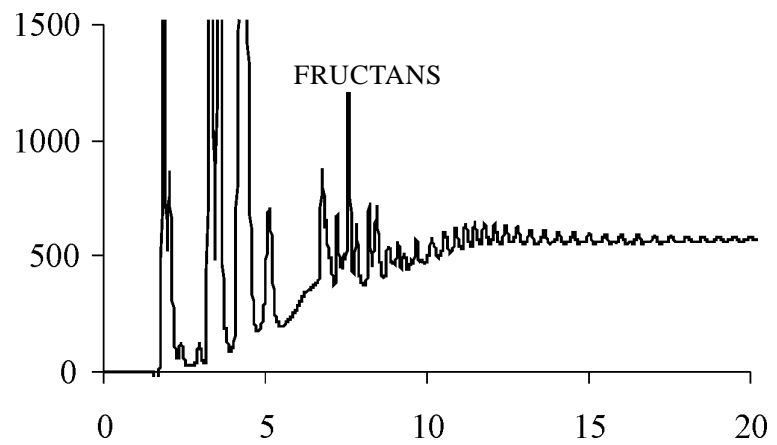

Retention time ( $\mathrm{min})$

Figure 2. HPAEC-PAD in CarboPac PA-1 column of the main water-soluble carbohydrates from the three grasses analyzed Echinolaena inflexa (A), Melinis minutiflora (B) and Lolium multiflorum $(\mathrm{C}) . \mathrm{G}=$ glucose, $\mathrm{F}=$ fructose, $\mathrm{S}=$ sucrose, $\mathrm{R}=$ raffinose. Fructans with low and high degree of polymerization eluted from 5 to $20 \mathrm{~min}$. Samples equivalent to $2.5 \mathrm{mg} \cdot \mathrm{gFM}^{-1}$ for M. minutiflora and E. inflexa.

A species in any time during the daylight period.

Results from the present work showed great similarity between $E$. inflexa and $M$. minutiflora in contents and composition of WSC (as previously reported by Moraes et al. 2002) and starch. According to Chatterton et al. (1991), oligosaccharides of the raffinose series,
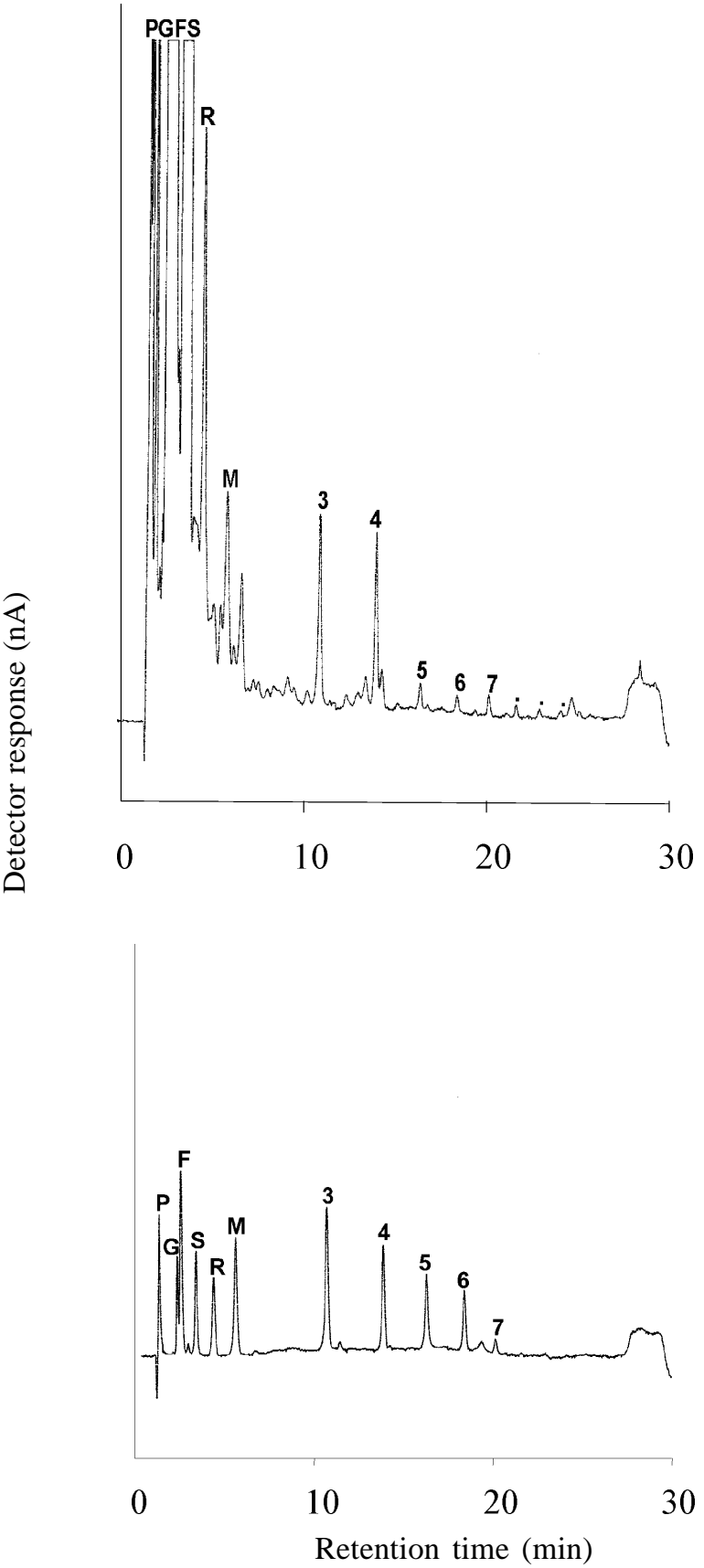

Figure 3. HPAEC-PAD in CarboPac PA-100 column of the main water-soluble carbohydrates $\left(4 \mathrm{mg} \cdot \mathrm{ml}^{-1}\right)$ from vegetative tissues of Echinolaena inflexa (A) and maltooligosaccharide standards (B). $\mathrm{P}=$ polyol, $\mathrm{G}=$ glucose, $\mathrm{F}=$ fructose, $\mathrm{S}=$ sucrose, $\mathrm{R}=$ raffinose, $\mathrm{M}=$ maltose . Numbers 3-7 indicate the degree of polymerization of maltooligosaccharides. 

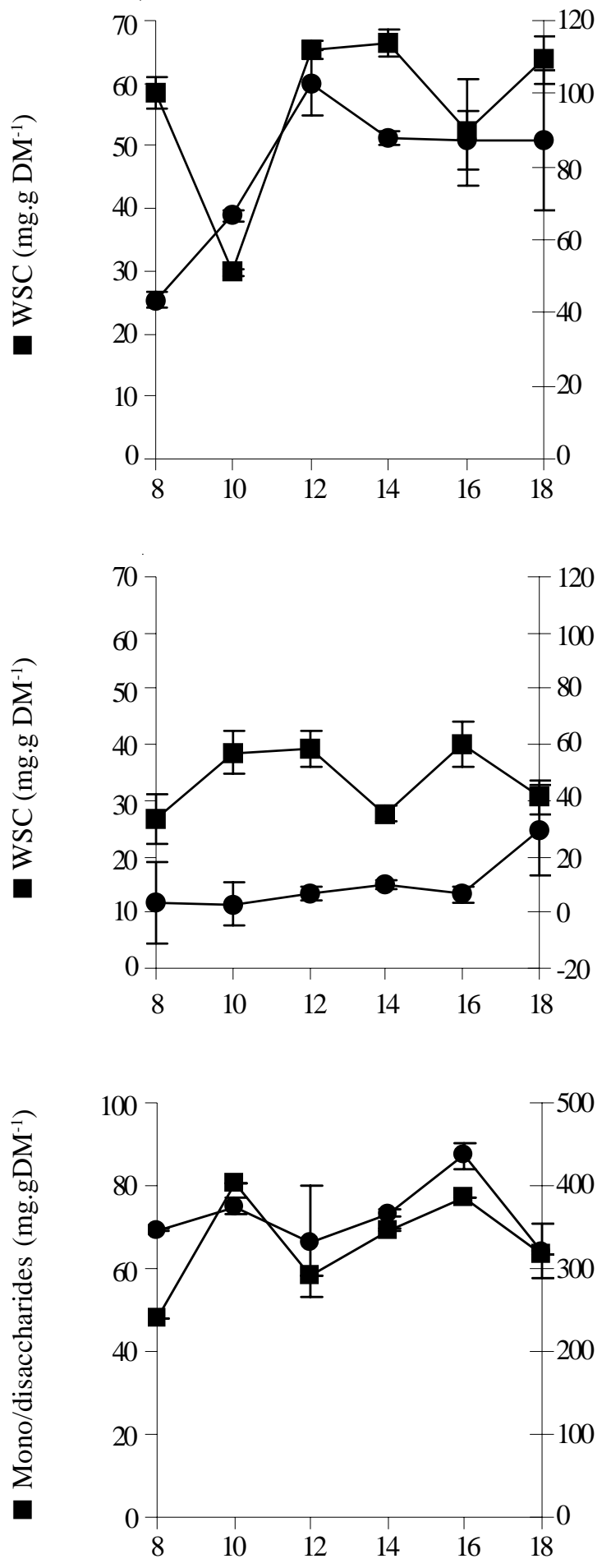

Time of the day (h)

Figure 4. Diurnal variations in the levels $\left(\mathrm{mg} . \mathrm{gDM}^{-1}\right)$ of total WSC $(\square)$ and starch (-) in aerial parts of Melinis minutiflora (A) and Echinolaena inflexa (B) and in monoand disaccharides (ם) and fructans ( ) from Lolium multiflorum (C). Bars indicate S.E. of the means. When not shown, they are smaller than the symbol.
A instead of fructans, can be present in higher amounts in $\mathrm{C} 4$ warm-season grasses. Although in low proportions, raffinose and maltose-based oligosaccharides were found in M. minutiflora and in E. inflexa (figures 2,3) growing in the cerrado and may be associated with their strategies to overcome seasonal drought and high temperature. The maltose-based oligosaccharides could be related to starch metabolism, since warmer temperatures seem to increase the activity of endo-amylases, producing relatively higher proportion of short glucans, as reported by Smith et al. (2003) for other grasses. Abiotic stresses have also been associated to the regulation of $\beta$-amylase activity, which produces maltose from polyglucan chains during transitory starch breakdown. This was observed in the fructan-accumulating barley (Dreier et al. 1995), and in starch accumulators, such as pearl millet and maize (Datta et al. 1999). Recently, Kaplan \& Guy (2004) verified the regulation of $\beta$-amylases activity by temperature in Arabidopsis and demonstrated compatible solute properties of maltose in vitro. The presence of soluble products of starch breakdown in $M$. minutiflora and $E$. inflexa could be helpful to protect the tropical grass species, when environmental conditions are unfavorable.

Glucose was the main carbohydrate associated to the fluctuations found in total WSC in M. minutiflora and E. inflexa. The levels of sucrose lower than those of glucose may indicate that, in these species, glucose variations could be more related to starch metabolism. In L. multiflorum, in contrast, the content of sucrose was much higher than those of glucose and fructose, clearly indicating the relationship between sucrose concentrations and fructan accumulation in the vegetative tissues of this species. According to Chatterton et al. (1989), a threshold value of approximately $15 \%$ NSC must be present before fructan begins to accumulate. Analysis of starch content in the aerial parts of L. multiflorum revealed very low concentrations (data not shown), compared to those found in the two other species analyzed. This result is consistent with the general pattern of low leaf- and high seed-starch concentrations in fructan-grasses.

Carbohydrate storage may provide a buffer against changes in irradiance during the day, being remobilized during periods of low irradiance to supply the rest of the plant (Servaites et al. 1989). This is especially important in $\mathrm{C} 4$ plants, which are subject to larger fluctuations in the rate of $\mathrm{CO}_{2}$ fixation during natural changes in irradiance during the day (Kalt-Torres et al. 1987). That is likely the case of the alien C4 grass species M. minutiflora, which showed higher variations in the 
content of NSC during the diurnal cycle when compared to the other grasses studied in the present work.

Studies carried out with C3 grasses from temperate regions showed that they can present a very distinct behavior concerning the diurnal variations in carbohydrate levels. Some species, such as Festuca arundinacea Screb., show a linear increase in the WSC content during the day (Lechtenber et al. 1972), while sugar concentrations in other grasses increase only in the morning, tending to stabilization in the afternoon period (Marais et al. 1993 apud Ciavarella et al. 2000). Results obtained in the present work indicate that each one of the three analyzed species has a particular pattern of diurnal carbohydrate metabolism.

According to Trevaskis et al. (2004), cows grazing short rotation Italian ryegrass pastures near Sydney (Australia) had a substantial benefit when their daily allocation of pastures was giving after afternoon milking, in the knowledge that WSC accumulated during the day. In Brazil, Italian ryegrass can represent more than $80 \%$ of the pasture composition during winter season in lowland areas of the Rio Grande do Sul State (Marchezan et al. 2002) and M. minutiflora and E. inflexa are important components of the herbaceous stratum in the cerrado, that is commonly used as pastures in Brazil. Although
Tropical grasses

A
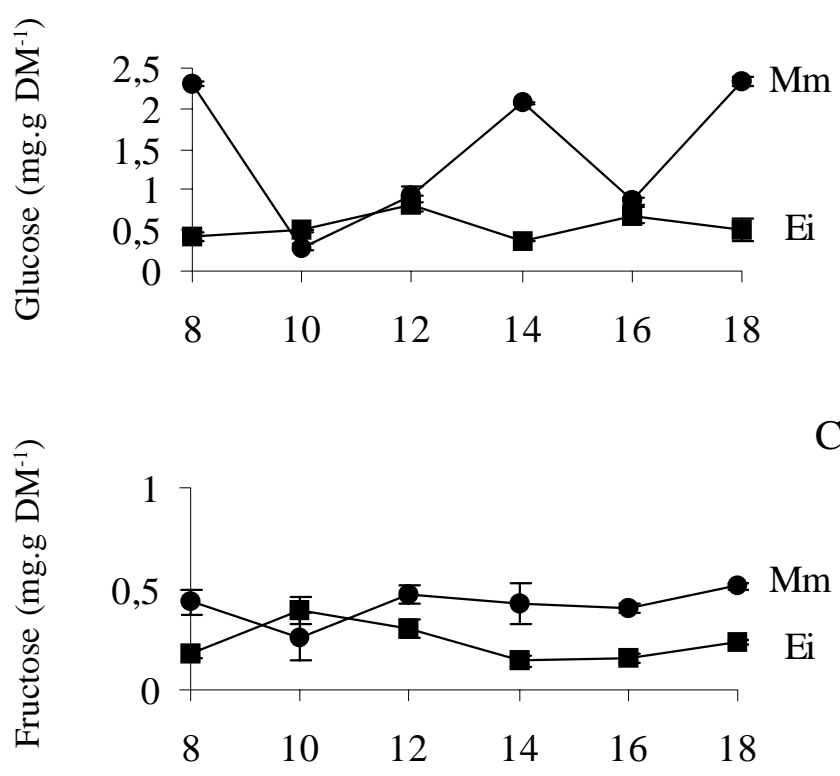

E

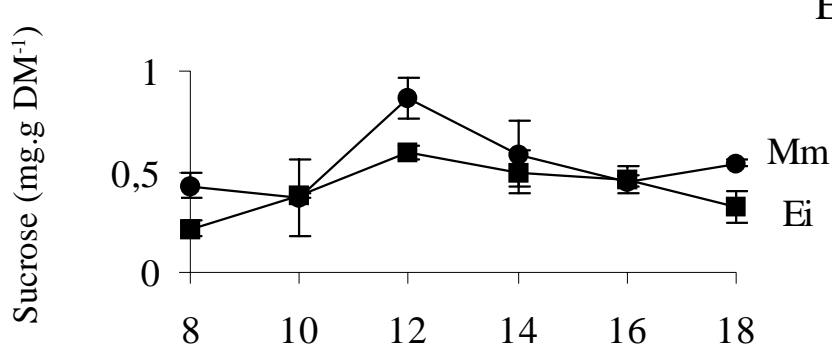

Time of the day (h)
Temperate grass

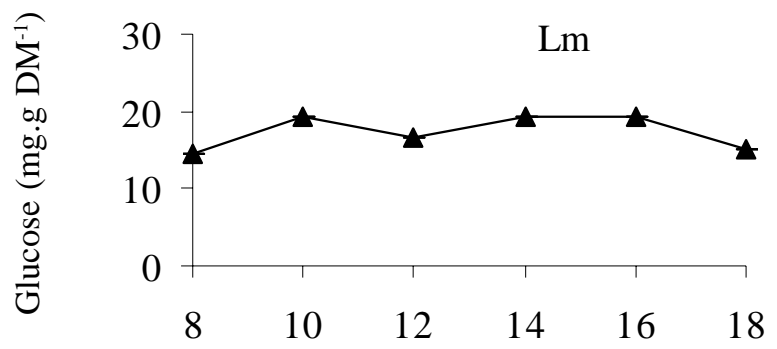

$\mathrm{C}$
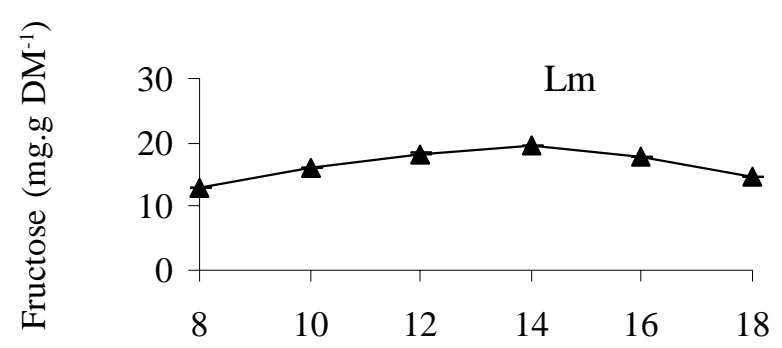

$\mathrm{D}$

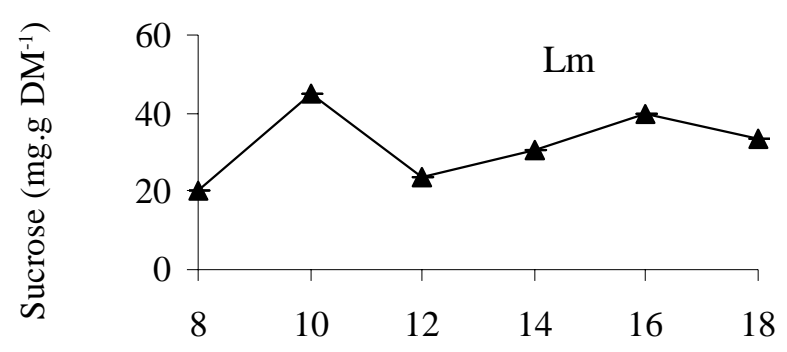

Time of the day (h)

Figure 5. Diurnal variations in the levels $\left(\mathrm{mg}_{\mathrm{gDM}} \mathrm{gD}^{-1}\right)$ of glucose (A, B), fructose (C, D) and sucrose (E, F) in aerial parts of Echinolaena inflexa (Ei - $\mathbf{0})$, Melinis minutiflora (Mm - - ) and Lolium multiflorum (Lm - $\mathbf{\Delta}$ ). Bars indicate S.E. of the means. When not shown, they are smaller than the symbol. 
based on one-day analyses, information obtained in the present work on diurnal variations of WSC in the three forage grasses may be important for future studies of selective grazing and contributed for an understanding of storage carbohydrates in forage grasses.

Acknowledgments - This work was supported by Fapesp within the Biota/Fapesp, The Biodiversity Virtual Institute Program (http://www.biotasp.org.br). The authors thank Dr. Marisa Domingos for the critical revision of the manuscript. M.G. Moraes thanks Capes for the doctoral fellowship, A. Souza thanks Fapesp for the Master fellowship, and C.Z. Sandrin thanks The National Research Council for the Development of Science $(\mathrm{CNPq})$ for PIBIC fellowship. R.C.L. Figueiredo-Ribeiro is a fellow researcher of CNPq.

\section{References}

ARÊAS, J.A.G. \& LAJOLO, F.M. 1980. Determinação enzimática específica de amido, glicose, frutose e sacarose em bananas pré-climatéricas e climatéricas. Anais de Farmácia e Química 20:307-318.

CAIRNS, A.J., BEGLEY, P. \& SIMS, I.M. 2002. The structure of starch from seeds and leaves of the fructan-accumulating ryegrass, Lolium temulentum L. Journal of Plant Physiology 159:221-230.

CASTRO, A.A.J., MARTINS, F.R., TAMASHIRO, J.Y. \& SHEPHERD, G.J. 1999. How rich is the flora of Brazilian cerrados? Annals of the Missouri Botanical Garden 86:192-224.

CHATTERTON, N.J., HARRISON, P.A., BENNETT, J.H. \& ASAY, K.H. 1989. Carbohydrate partitioning in 185 accessions of Gramineae grown under warm and cool temperatures. Journal of Plant Physiology 134:169-179.

CHATTERTON, N.J., THORNLEY, W.R., HARRISON, P.A. \& BENNETT, J.H. 1991. DP-3 and DP-4 oligosaccharides in temperate and tropical grass foliage grown under cool temperatures. Plant Physiology and Biochemistry 29:367-372

CIAVARELLA, T.A., SIMPSON, R.J., DOVE, H.,LEURY, B.J. \& SIMS, I.M. 2000. Diurnal changes in the concentration of water-soluble carbohydrates in Phalaris aquatica L. pasture in spring, and the effect of short-term shading. Australian Journal of Agricultural Research 51:749-756.

DATTA, R., SELVI, M.T., SEETHARAMA, N. \& SHARMA, R. 1999. Stress-mediated enhancement of beta-amylase activity in pearl millet and maize leaves is dependent on light. Journal of Plant Physiology 154:657-664.

DOMINGOS, M., KLUMPP, A. \& KLUMPP, G. 1998. Air pollution impact on the Atlantic forest in the Cubatão region, SP, Brazil. Ciência e Cultura 50:230-236.

DREIER, W., SCHNARRENBERGER, C. \& BÖRNER, T. 1995. Light- and stress-dependent enhancement of amylolytic activities in white and green barley leaves: beta-amylases are stress-induced proteins. Journal of Plant Physiology 145:342-348.
DUBOIS, M., GILLES, A., HAMILTON, J.K., REBERS, P.A. \& SMITH, F. 1956. Colorimetric method for determination of sugars and related substances. Analytical Chemistry 28:350-355.

FILGUEIRAS, T.S. 1991. A floristic analysis of the Gramineae of Brazil's Distrito Federal and a list of the species occurring in the area. Edinburgh Journal of Botany 48:73-80.

GRIFFITH, S.M. 1992. Changes in post-anthesis assimilates in stem and spike components of Italian Ryegrass (Lolium multiflorum Lam.). I. Water soluble carbohydrates. Annals of Botany 69:243-248.

HENDRY, G.A.F. 1993. Evolutionary origins and natural functions of fructans - a climatological, biogeographic and mechanistic appraisal. New Phytologist 123:3-14.

ITAYA, N.M., BUCKERIDGE, M.S. \& FIGUEIREDORIBEIRO, R.C.L. 1997. Biosynthesis in vitro of highmolecular-mass fructan by cell-free extracts from tuberous roots of Viguiera discolor (Asteraceae). New Phytologist 136:53-60.

JERMYN, M.A. 1956. A new method for the determination of ketohexoses in the presence of aldohexoses. Nature 177:38.

KALT-TORRES, W., KERR, P.S., USUDA, H. \& HUBER, S.C. 1987. Diurnal changes in maize leaf photosynthesis I. Carbon exchange rate, assimilate export rate, and enzyme activities. Plant Physiology 83:283-288.

KAPLAN, F. \& GUY, C.L. 2004. $\beta$-Amylase induction and the protective role of maltose during temperature shock. Plant Physiology 135:1674-1684.

LECHTENBERG V.L.,HOLT, D.A. \& YOUNGBERG H.W. 1972. Diurnal variation in nonstructural carbohydrates of Festuca arundinacea (Schreb.) with and without N fertilizer. Agronomy Journal 64:302-305.

LUNN, J.E. \& HATCH, M.D. 1995. Primary partitioning and storage of photosynthate in sucrose and starch in leaves of C4 plants. Planta 197:385-391.

MANTOVANI, W. \& MARTINS, F.R. 1988. Variações fenológicas das espécies do cerrado da Reserva Biológica de Moji-Guaçu, Estado de São Paulo. Revista Brasileira de Botânica 11:101-112.

MARCHEZAN, E., VIZZOTO, V.R., ROCHA, M.G., MOOJEN, E.L. \& SILVA, J.H.S. 2002. Produção animal em várzea sistematizada cultivada com forrageiras de estação fria submetidas a diferentes níveis de adubação. Ciência Rural 32:303-308.

MORAES, M.G. 2001. Carboidratos solúveis de gramíneas do cerrado. Tese de Doutorado. Universidade de São Paulo, São Paulo.

MORAES, M.G., SOUZA, A., PESSONI, R.A.B. \& FIGUEIREDO-RIBEIRO, R.C.L. 2002. Soluble carbohydrate similarities between Echinolaena infllexa and Melinis minutiflora (Poaceae). Hoehnea 29:151-158.

OJIMA, K. \& ISAWA, T. 1968. The variation of the carbohydrates in various species of grasses and legumes. Canadian Journal of Botany 46:1507-1511. 
POLLOCK, C.J. \& CAIRNS, A.J. 1991. Fructan metabolism in grasses and cereals. Annual Review of Plant Physiology and Molecular Biology 42:77-101.

POLLOCK, C.J. \& CHATTERTON, N.J. 1988. Fructans. In The biochemistry of plants: a comprehensive treatise (J. Preiss, ed.). Academic Press, London, v.14, p.109-140.

POLLOCK, C.J. \& JONES, T. 1979. Seasonal patterns of fructans metabolism in forage grasses. The New Phytologist 83:9-15.

SANDRIN, C.Z., DOMINGOS, M. \& FIGUEIREDORIBEIRO, R.C.L. 2004. Fructan changes in Lolium multiflorum ssp. italicum "Lema" as an indicator of urban air pollution. In Urban air pollution, bioindication and environmental awareness (A. Klumpp, W. Ansel \& G. Klumpp, eds.). Cuvillier Verlag, Göttingen, p.293-301.

SERVAITES, J.C., FONDY, B.R., LI, B. \& GEIGER, D.R. 1989. Source of carbon for export from spinach leaves throughout the day. Plant Physiology 90:1168-1174.
SMITH, A.M., ZEEMAN, S.C., THORNEYCROFT, D. \& SMITH, S.M. 2003. Starch mobilization in leaves. Journal of Experimental Botany 54:577-583.

SMOUTER, H. \& SIMPSON, R.J. 1989. Occurrence of fructans in the Gramineae (Poaceae). New Phytologist 111:359-368.

TIMMERMANS, J.W., VAN LEEUWEN, M.B., TOURNOIS, H., DE WIT, D. \& VLIEGENTHART, J.F.G. 1994. Quantitative analysis of the molecular weight distribution of inulin by means of anion exchange HPLC with pulsed amperometric detection. Journal of Carbohydrate Chemistry 13:881-888.

TREVASKIS, L.M., FULKERSON, W.J. \& NANDRA, K.S. 2004. Effect of time of feeding carbohydrate supplements and pasture on production of dairy cows. Livestock Production Science 85:275-285. 